\title{
Estimating suspended sediment concentration at different time scales in Northeastern Algeria
}

\author{
Salah Eddine Tachi ${ }^{1}$ (1) Hamza Bouguerra ${ }^{2} \cdot$ Oussama Derdous $^{1,3} \cdot$ Larbi Djabri $^{2} \cdot$ Saâdia Benmamar $^{1}$
}

Received: 29 February 2020 / Accepted: 14 April 2020 / Published online: 23 April 2020

(c) The Author(s) 2020

\begin{abstract}
It is known that water erosion and their suspended sediments transport, generally in the Maghreb region and particularly in Algeria, record very high values; knowledge of these sediments is a very important step in planning erosion control measures. In this study, we modeled and quantified suspended sediment in the Ressoul wadi, Seybouse basin in northeastern Algeria. The study was carried out at different time scales, during a period of 32 years from 1968/69 to 1999/2000 by establishing regressions between the measured sediment concentration and the water discharge at the watershed outlet. The results obtained by the proposed method indicate that the use of two regressions based on means of discharge classes technique reveals very good estimation of the suspended sediment load in the Ressoul wadi, with an error of $3.04 \%$ and a specific average degradation transported to the downstream of the watershed of $316.45 \mathrm{t} / \mathrm{km}^{2} /$ year in the period of 32 years.
\end{abstract}

Keywords Regression $\cdot$ Discharge classes $\cdot$ Erosion $\cdot$ Sediment concentration $\cdot$ Quantification $\cdot$ Watershed $\cdot$ Ressoul wadi . Algeria

\section{Introduction}

Among the major environmental problems that hydrologists are dealing with, nowadays the silting and solid transport is caused by water erosion. The quantification of the suspended sediment load in catchments is of great importance as it affects directly the management of different hydro- and ecosystems as well as the morphological issues in watersheds.

The annual suspended sediment load of the stream is generally determined either from direct measurements of the sediment throughout the year or from different empirical equations that are available (Jansson and Erlingsson 2000; Khanchoul et al. 2009). The estimation of suspended sediment load in small streams with rapid discharge variations is still of great challenge between researchers till today. Different methods were applied by scientists in the Maghreb

Salah Eddine Tachi

salah_eddine.tachi@g.enp.edu.dz

1 Laboratoire de recherche science de l'eau, Ecole National Polytechnique, 10 Rue des Frères OUDEK, 16200 El Harrach, Algiers, Algeria

2 Laboratoire Ressource en Eau et Développement Durable, Université Badji Mokhtar - Annaba, 23000 Annaba, Algeria

3 University of KasdiMerbah, 33000 Ouergla, Algeria region in finding relation between hydro-climatic parameters and the suspended sediment load, among those methods were: the regression models (Walling 1984; Khanchoul et al. 2007; Khanchoul and Jansson 2008; Bouchelkia et al. 2013; Balla et al. 2017), empirical models (Bouguerra et al. 2017; Mukanov et al. 2019) and artificial intelligence techniques (Tachi et al. 2016; Bouzeria et al. 2017; Bouguerra et al. 2019). Regardless of the sediment rating curves general use, numerous problems are recognized regarding the accuracy of the fitted curve as well as the physical meaning of its regression coefficients (Khanchoul and Jansson 2008).

In the last decade, different researchers succeed to estimate suspended sediment discharge based on water discharge and previous values of suspended sediment discharge using artificial neural network and machine learning. Thus, these techniques did not show high accuracy in predicting suspended sediment concentration depending on water discharge (Tachi et al. 2016). The difficulty in predicting suspended sediment concentration using artificial techniques is due to the complex relation between water discharge and sediment concentration. According to many analyses applied on the available data in northern Algeria, important factors conditioning suspended sediment are the intensity of rainfall during dry seasons and the connectivity of drainage network of the watershed which are not introduced to the artificial 
intelligence models, whereas the quantity of water discharge is low and sediment concentration is high during dry periods, and water discharge is high and sediment concentration is high as well during wet seasons which lead to the weak generalization and optimization of the artificial intelligence models.

For better quantification of sediment loads, a sediment rating curve technique that was proposed by Jansson (1985, 1996) for rating the relationship between sediment loads and water discharge, it is based on sorting and regrouping the data into mean of discharge-based classes. Basically, it is based on the calculation of average concentrations and average flow rates, which gives more correct order of magnitude of the sediment yields estimation and eliminates to some re-transformation bias problems which complicate the rating curve technique (Jansson 1985, 1996; Khanchoul et al. 2009). The proposed technique by Jansson (1996) showed a very efficient estimation of suspended sediment yields even though the rarely use of the last one; we enumerate among researchers (Koch and Smillie 1986a, b; Stow et al. 2006; Ono et al. 2011; Hu et al. 2011; Balla et al. 2017).

The aim of this study is to estimate suspended sediment load in the Ressoul wadi, Seybouse basin, using the regression between sediment concentration and water discharge. The sediment rating curve was developed by dividing the data into discharge-based classes due to the noticeable variation in the suspended sediment concentrations with stages and seasons and by comparing the sediment yields quantification whether using annual or seasonal time scales.

\section{Materials and methods}

\section{Study area and data set}

The study area comprises the watershed of the wadi Ressoul, which is a sub-watershed of the Seybouse basin, North-Eastern Algeria. It is located in maritime Seybouse between the latitudes $36^{\circ} 32^{\prime} 56^{\prime \prime}-36^{\circ} 40^{\prime} 51^{\prime \prime} \mathrm{N}$ and the longitudes $07^{\circ} 27^{\prime} 51^{\prime \prime}-07^{\circ} 36^{\prime} 51^{\prime \prime}$ E. Its total area is $103 \mathrm{~km}^{2}$ for a perimeter of $50 \mathrm{~km}$, and a principal thalweg of the Ressoul wadi watershed of $25 \mathrm{~km}$ (Fig. 1).

The data sets of the presented research comprising instantaneous water elevations $[\mathrm{cm}]$ and suspended sediment concentrations $[\mathrm{g} / \mathrm{l}]$ were collected from the National Agency for Hydraulic Resources (ANRH) which is managing all the hydrometric necessary measurements in watersheds and controls the water resources in different Algerian rivers by implanting different hydrometric, rainfall and water quality analysis stations.

The data collected are the instantaneous water elevations in $(\mathrm{cm})$ and the suspended sediment concentrations in $(\mathrm{g} / \mathrm{l})$ at the hydrometric station between the period 1968/69 and 1999/00. The water heights have been transformed into liquid flows using the calibration curve (Fig. 2). The latter was obtained by using the results of gauging with the reel provided measurement data by the ANRH, and which includes 276 values of gauging carried out between December 1968 and October 2012. It can be seen that there are 19 values which have been deleted that are badly positioned on the calibration curve (Fig. 2), especially in low-water elevations.

The data were carried out from 1968/1969 to 1999/2000 at Ain Berda station. The suspended sediment discharges were calculated by the following formula (1):

$$
\mathrm{SSD}=\mathrm{WD} * \mathrm{SSC}
$$

Fig. 1 Location map of the Ressoul catchment

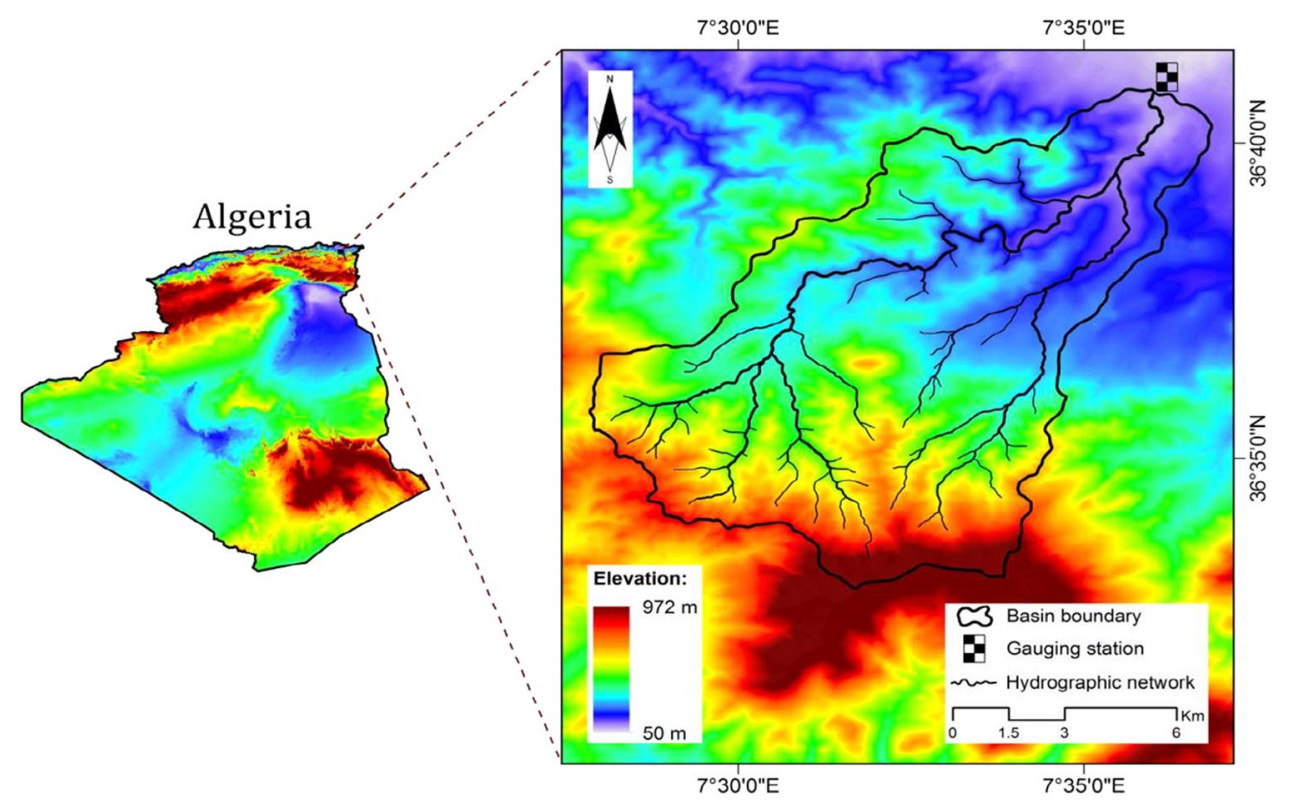


Fig. 2 The calibration curve of the Ain Berda hydrometric station

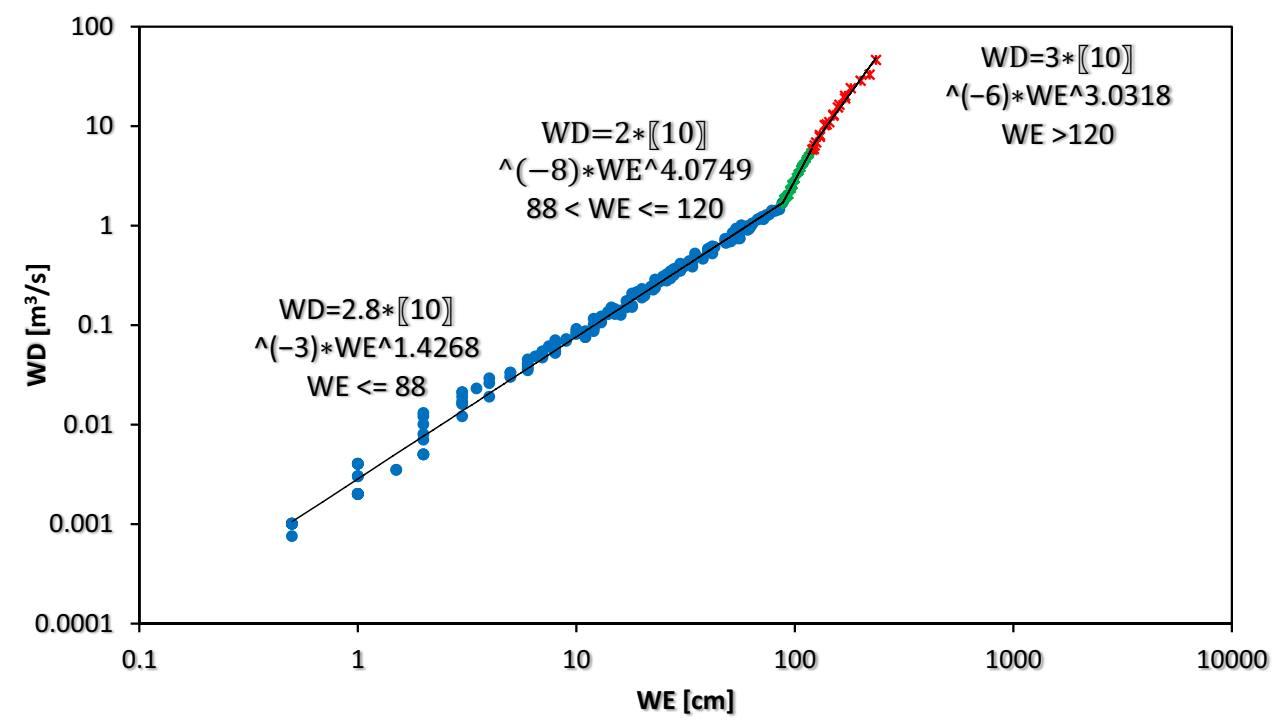

where SSD = suspended sediment discharge, SSC $=$ suspended sediment concentration and $\mathrm{WD}=$ water discharge.

\section{Gaussen ombro-thermal diagram}

The Gaussen ombro-thermal diagram was established based on monthly inter-annual averages of precipitation and temperatures recorded at the Saline weather station in Annaba. The results show the existence of two very distinct periods: one dry, which lasts from April 26 to September 09, and the other wet, which runs from the end till the beginning of dry period, which can last around 30 weeks (Fig. 3).

\section{Method}

The discharge-based classes technique proposed by Jansson $(1985,1996)$ was used in the present study for rating the relationship between sediment load and water discharge, and it is based on sorting and regrouping the data into discharge-based classes, by the calculation of average concentrations and average water discharge rates. Furthermore, computer programs, such as Excel, do not correct the bias of the re-transformed equation when calculating all data by log-transformation using power regression, when there



Fig. 3 Ombro-thermal chart of the Salin meteorological station (1989-2017) 
is such series data as the presented in this work, there is a great difference between the means of the re-transformed values and the means of un-logged values along the regression curve (Khanchoul and Jansson 2008). The proposed technique gives more correct order of magnitude of the sediment load and eliminates to some re-transformation bias problems which complicate the rating curve technique (Jansson 1985, 1996; Khanchoul et al. 2009).

$C=a * \mathrm{WD}^{b}$

$C$ is sediment concentration, WD is water discharge, and $a$ and $b$ are regression parameters.

The bias is due to the fact that a re-transformed mean of logged values differs from the mean of the non-logged values. Thus, the bias of the re-transformed equation must be corrected. Miller (1984) proposed the following bias correction factor $\mathrm{CF}$.

$C=(a * \mathrm{CF}) * \mathrm{WD}^{b}$

$\mathrm{CF}$ correction factor

$\mathrm{CF}=\exp \left(0.5 * \delta^{2}\right)$

where

$\delta^{2}=\frac{1}{(N-1)} * \sum_{i=1}^{N}\left(\ln C_{i_{\mathrm{obs}}}-\ln C_{i_{\mathrm{est}}}\right)^{2}$

$c f$ is the correction factor, $N$ is simple size and $\delta^{2}, C_{i_{\mathrm{obs}}}$ and $C_{i_{\text {est }}}$ are the variance, the measured and estimated concentration, respectively. The general corrected equation becomes as follows:

$C=(a * \mathrm{CF}) * \mathrm{WD}^{b}$

The suspended sediment discharge is estimated as follows:

$\mathrm{SSD}=\mathrm{WD} * C$

SSD suspended sediment discharge

Errors have been calculated and expressed as the percentage of the calculated and the measured sediment discharge data as follows:

Error $[\%]=\left(\frac{\mathrm{SSD}_{\mathrm{est}}}{\mathrm{SSD}_{\mathrm{obs}}}-1\right) * 100$

SSD $_{\text {est }}$ estimated suspended sediment discharge values, and $\mathrm{SSD}_{\text {obs }}$ observed suspended sediment discharge values.

\section{Results and discussion}

For a better estimation of suspended sediment concentration, a power model based on the means of water discharge classes was developed by linking the suspended sediment concentration with water discharge using one regression and multiple regressions (Table 1).

To achieve more reliable sediment rating curve and accurate estimation of sediment yields, two regression techniques based on the means of water discharge proposed by Jansson (1985) were used in this work; the first is the single
Table 1 Performance results of the suspended sediment at different time scales

\begin{tabular}{lllllll}
\hline Data groups & Threshold $\left(\mathrm{m}^{3} / \mathrm{s}\right)$ & Relationship & $\delta^{2}$ & $\mathrm{CF}$ & $R^{2}$ & Size \\
\hline All data & Only one regression & $C=1.1897 * \mathrm{WD}^{0.4187}$ & - & - & 0.95 & 3135 \\
& WD $\leq 1.53$ & $C=1.1440 * \mathrm{WD}^{0.4195}$ & - & - & 0.91 & \\
\multirow{3}{*}{ Winter } & WD $>1.53$ & $C=1.5432 * \mathrm{WD}^{0.3320}$ & - & - & 0.75 & \\
& Only one regression & $C=1.1167 * \mathrm{WD}^{0.4539}$ & 0.172 & 1.090 & 0.88 & 1343 \\
& WD $\leq 0.81$ & $C=1.3049 * \mathrm{WD}^{0.5412}$ & 0.174 & 1.091 & 0.82 & \\
Spring & WD $>0.81$ & $C=1.2616 * \mathrm{WD}^{0.3959}$ & 0.157 & 1.082 & 0.70 & \\
& Only one regression & $C=0.5918 * \mathrm{WD}^{0.4825}$ & - & - & 0.91 & 1133 \\
& WD $\leq 1.61$ & $C=0.5804 * \mathrm{WD}^{0.4727}$ & - & - & 0.74 & \\
Summer and fall & Only one regression & $C=2.2365 * \mathrm{WD}^{0.4807}$ & - & - & 0.84 & 659 \\
& WD $\leq 0.85$ & $C=2.6706 * \mathrm{WD}^{0.5680}$ & - & - & 0.74 & \\
& WD $>0.85$ & $C=2.9546 * \mathrm{WD}^{0.3385}$ & - & - & 0.50 & \\
Dry period & Only one regression & $C=0.7071 * \mathrm{WD}^{0.4435}$ & 0.488 & 1.276 & 0.74 & 382 \\
& WD $\leq 0.54$ & $C=0.3245 * \mathrm{WD}^{0.1878}$ & 0.356 & 1.195 & 0.18 & \\
& WD $>0.54$ & $C=0.6337 * \mathrm{WD}^{0.5517}$ & 0.481 & 1.272 & 0.66 & \\
Wet period & Only one regression & $C=1.2227 * \mathrm{WD}^{0.4013}$ & - & - & 0.93 & 2753 \\
& WD $\leq 0.52$ & $C=1.2889 * \mathrm{WD}^{0.4305}$ & - & - & 0.86 & \\
& WD $>0.52$ & $C=1.2992 * \mathrm{WD}^{0.3762}$ & - & - & 0.80 & \\
\hline
\end{tabular}



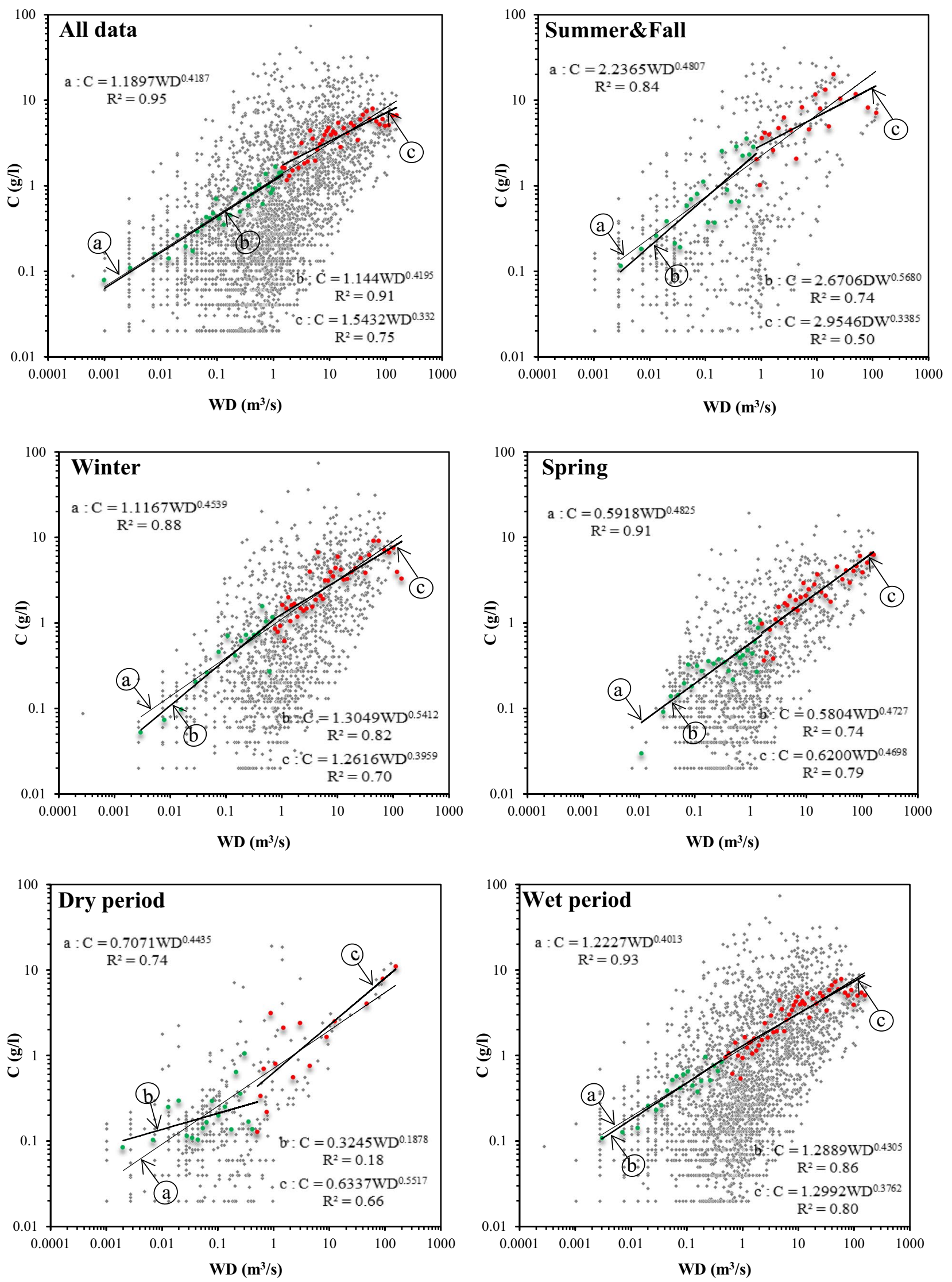

Fig. 4 Scatter plots of the annual, seasonal and periodical rating curve developed on means (WD and $C$ ); a rating from a single best-fit calculation; b rating from low-medium flow; c rating from high-flow 
regression, and the second is multiple regression technique which is basing the data dividing on the water discharge threshold at the studied times scales.

Table 1 presents the performance results of the annual data using two regression techniques; the one regression equation presents the relation of water discharge and the sediment concentration of all discharge classes-based data. The multiple regression is based on the water discharge threshold technique, and it presents two different equations based on two discharge classes, the first one where the water discharge is inferior or equal to threshold value of each time scale and the second equation represents the data of water discharge which is equal or superior to threshold value of each time scale.

Sediment rating curves were developed on all means of water discharges, and suspended sediment concentrations are illustrated in Fig. 4 and Table 1. Contrarily, only using one regression based on the means of sediment rating curves, it is difficult to fit the means values of high and low loads (Fig. 4). The high important amount of transported suspended yields is during flood events. Thus, the data were divided into two groups which creating two regression lines based on water discharge threshold (Fig. 4, Table 1). The apparent change (Fig. 4) of the line through the means was the base of dividing the sediment rating curve. Table 1 presents the comparison between measured suspended sediment and calculated suspended sediment with and without correction for bias using the constructed sediment rating curve.

The measured data also presented in Table 1 are divided into seasons, dry and wet periods. The means indicated that under-fitting occurred in two periods, during winter and dry periods. The correlation coefficient $(R)$ showed higher values using one regression than using two regressions, with the highest correlation presented using all data (0.95), followed by wet period, spring, winter, summer and fall and dry periods with $R(0.93,0.91,0.88,0.84$ and 0.74$)$, respectively.

Table 2 presents the suspended sediment yields quantification in the Ressoul wadi using water discharge-based classes. The quantification of suspended sediment was based on the two techniques developed in this study and presented above.

Table 2 presents the quantification of sediment yields in the Ressoul wadi that is based on the obtained equations from Table 1, the quantification using only one regression with $R 0.95$ showed an error of $11.24 \%$, whereas using two regressions with $R 0.91$ and 0.75 showed an error of $3.04 \%$. That is to say, the quantification based on two regressions gave better quantification of suspended sediment yields than using only one regression with calculated sediment yields of 90,837 tons. The calculated specific degradation of the Ressoul wadi using the two regressions was $316.46 \mathrm{t} / \mathrm{km}^{2} /$ an during the period of 32 years studied herein.

During the seasonal quantification, the best-obtained quantifications were presented during spring season, whereas the use of two regressions technique showed lesser error than using single regression, while the fit was higher in the single regression equation than the two regressions with an error of 3.41 and 2.67, respectively. Followed by winter quantification, with an error of -3.72 and -11.74 where it explained the underestimation of suspended sediment yields using one regression and two regressions, respectively. High errors were presented in using only single regression with 71.71 during summer and fall season and 29.20 using two regressions.

The quantification of suspended sediment yielded during wet period showed lesser errors than dry period with $8.31,-35.71$ using one regression and 4.59 and -6.33 using two regressions, respectively, with superiority of using two regressions in both models. Moreover, the underestimation

Table 2 Suspended sediment loads in the Ressoul wadi

\begin{tabular}{|c|c|c|c|c|c|c|}
\hline$\sum$ SSD from obser & lata & Procedure & $\begin{array}{l}\sum \text { SSD (tons) with } \\
\text { uncorr. relationship }\end{array}$ & Error $(\%)$ & $\begin{array}{l}\sum \mathrm{SSD} \text { (tons) with } \\
\text { corr. relationship }\end{array}$ & Error $(\%)$ \\
\hline All data & 88,158 & One single regression & 98,063 & 11.24 & - & - \\
\hline & & Two regressions & 90,837 & 3.04 & - & - \\
\hline Winter & 42,909 & One single regression & 41,313 & -3.72 & 45,030 & 4.94 \\
\hline & & Two regressions & 37,987 & -11.47 & 41,100 & -4.22 \\
\hline Spring & 30,637 & One single regression & 31,681 & 3.41 & - & - \\
\hline & & Two regressions & 31,456 & 2.67 & - & - \\
\hline Summer and Fall & 14,612 & One single regression & 25,089 & 71.71 & - & - \\
\hline & & Two regressions & 18,878 & 29.20 & - & - \\
\hline Dry period & 7860 & One single regression & 5053 & -35.71 & 6450 & -17.93 \\
\hline & & Two regressions & 7362 & -6.33 & 9361 & 19.11 \\
\hline Wet period & 80,298 & One single regression & 86,970 & 8.31 & - & - \\
\hline & & Two regressions & 83,985 & 4.59 & - & - \\
\hline
\end{tabular}


of sediment yields appeared during dry period and the use of the correction factor improved the error in both regressions with -17.93 using one regression and 19.11 using two regressions.

The performance results are based on the comparison of suspended sediment yields quantification using two different regressions techniques. It can be seen from Table 1 that the coefficient of determination using one regression is higher than using two regressions technique, where it shows higher goodness of fit using only one regression with $R^{2} 95 \%$ and goodness of fit of two regressions $R^{2} 91 \%$ and $75 \%$. Contrarily, in quantifying the sediment yields, using the two regressions is more accurate and shows lesser errors comparing to one regression with errors of $3.04 \%$ and $11.24 \%$, respectively.

\section{Conclusions}

In the present study, the discharge-based classes technique was used for rating the relationship between sediment concentration and water discharge for better sediment yield estimation in the Ressoul wadi, northeastern Algeria. It is based on sorting and regrouping the data into dischargebased classes by the calculation of average concentration and average water discharge rates. Two regression techniques were proposed, single regression and two regressions based on the water discharge threshold in different studied time scales.

In the present study, the correlation coefficient using single regression showed higher values than using two regressions, but contrary to the quantification of suspended sediment loads, the two regressions technique showed lesser errors and close quantification values of suspended sediment yield compared with observed data. Despite the wide scatter of the suspended sediment concentration, and the hard linking of the latter one with water discharge, the sediment rating curve that was developed using regressions based on means of discharge classes gave very satisfactory quantification of suspended sediment yields.

We aim in the future to model and estimate the sediment yields in Algerian watersheds using morphological indices based on remote sensing and artificial intelligence techniques.

Funding This study was funded by the Algerian ministry of higher education and scientific research.

\section{Compliance with ethical standards}

Conflict of interest The authors declare that they have no conflict of interest.
Open Access This article is licensed under a Creative Commons Attribution 4.0 International License, which permits use, sharing, adaptation, distribution and reproduction in any medium or format, as long as you give appropriate credit to the original author(s) and the source, provide a link to the Creative Commons licence, and indicate if changes were made. The images or other third party material in this article are included in the article's Creative Commons licence, unless indicated otherwise in a credit line to the material. If material is not included in the article's Creative Commons licence and your intended use is not permitted by statutory regulation or exceeds the permitted use, you will need to obtain permission directly from the copyright holder. To view a copy of this licence, visit http://creativecommons.org/licenses/by/4.0/.

\section{References}

Balla F, Kabouche N, Khanchoul K, Bouguerra H (2017) Hydro-sedimentary flow modelling in some catchments Constantine highlands, case of Wadis Soultez and Reboa (Algeria). J Water Land Dev 34(1):21-32

Bouchelkia H, Belarbi F, Remini B (2013) Estimated flows of suspended solids by the statistical analysis of outfall drainage basin of Tafna (Algeria). Soil Water Res 8(2):63-70

Bouguerra H, Bouanani A, Khanchoul K, Derdous O, Tachi SE (2017) Mapping erosion prone areas in the Bouhamdane watershed (Algeria) using the revised universal soil loss equation through GIS. J Water Land Dev 32(1):13-23

Bouguerra H, Tachi SE, Derdous O, Bouanani A, Khanchoul K (2019) Suspended sediment discharge modeling during flood events using two different artificial neural network algorithms. Acta Geophys 67(6):1649-1660

Bouzeria H, Ghenim AN, Khanchoul K (2017) Using artificial neural network (ANN) for prediction of sediment loads, application to the Mellah catchment, northeast Algeria. J Water Land Dev 33(1):47-55

Hu B, Wang H, Yang Z, Sun X (2011) Temporal and spatial variations of sediment rating curves in the Changjiang (Yangtze River) basin and their implications. Quatern Int 230(1-2):34-43

Jansson MB (1985) Comparison of retransformed logarithmic regressions and power function regressions. Geogr Ann 67A:61-70

Jansson MB (1996) Estimating a sediment rating curve of the Reventazon river at Palomo using logged mean loads within discharge classes. J Hydrol 183(3-4):227-241

Jansson MB, Erlingsson U (2000) Measurement and quantification of a sedimentation budget for a reservoir with regular flushing. Regul Rivers Res Manag Int J Devoted River Res Manag 16(3):279-306

Khanchoul K, Jansson MB (2008) Sediment rating curves developed on stage and seasonal means in discharge classes for the Mellah wadi, Algeria. Geogr Ann Ser A Phys Geogr 90(3):227-236

Khanchoul K, Jansson MB, Lange J (2007) Comparison of suspended sediment yield in two catchments, northeast Algeria. Z Geomorphol 51(1):63-94

Khanchoul K, Altschul R, Assassi F (2009) Estimating suspended sediment yield, sedimentation controls and impacts in the Mellah Catchment of Northern Algeria. Arab J Geosci 2(3):257-271

Koch RW, Smillie GM (1986a) Bias in hydrologic prediction using log-transformed regression models 1. JAWRA J Am Water Resour Assoc 22(5):717-723

Koch RW, Smillie GM (1986b) Comment on "River loads underestimated by rating curves" by RI Ferguson. Water Resour Res 22(13):2121-2122

Miller DM (1984) Reducing transformation bias in curve fitting. Am Stat 38(2):124-126

Mukanov Y, Chen Y, Baisholanov S, Amanambu AC, Issanova G, Abenova A, Fang G, Abayev N (2019) Estimation of annual

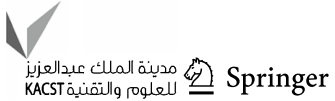


average soil loss using the Revised Universal Soil Loss Equation (RUSLE) integrated in a Geographical Information System (GIS) of the Esil River basin (ERB), Kazakhstan. Acta Geophys 67(3):921-938

Ono K, Akimoto T, Gunawardhana LN, Kazama S, Kawagoe S (2011) Distributed specific sediment yield estimations in Japan attributed to extreme-rainfall-induced slope failures under a changing climate. Hydrol Earth Syst Sci 15(1):197-207

Stow CA, Reckhow KH, Qian SS (2006) A Bayesian approach to retransformation bias in transformed regression. Ecology 87(6):1472-1477
Tachi SE, Ouerdachi L, Remaoun M, Derdous O, Boutaghane H (2016) Forecasting suspended sediment load using regularized neural network: case study of the Isser River (Algeria). J Water Land Dev 29(1):75-81

Walling DE (1984) The sediment yields of African rivers. IAHS-AISH publication, (144), pp 265-283

Publisher's Note Springer Nature remains neutral with regard to jurisdictional claims in published maps and institutional affiliations. 